\title{
HUBUNGAN TINGKAT PENGETAHUAN DAN KEPATUHAN \\ TERHADAP WAKTU KESEMBUHAN PENYAKIT SCABIES PADA SANTRI DI YAYASAN ISLAM AL-SYA'IRIYAH
}

\section{THE RELATIONSHIP BETWEEN KNOWLEDGE LEVELS AND COMPLIANCE WITH SCABIES HEALING TIME IN SANTRI AT THE AL-SYA'IRIYAH ISLAMIC}

\author{
Khabibatul Khikmah", Ainun Muthoharoh ${ }^{2}$, Wulan Agustin Ningrum ${ }^{3}$, St. \\ Rahmatullah $^{4}$ \\ ${ }^{l}$ Program Studi Sarjana Farmasi, Fakultas Ilmu Kesehatan, Universitas Muhammadiyah \\ Pekajangan Pekalongan \\ Jl. Raya Ambuekembang No.8 Kedungwuni, Pekalongan, Jawa Tengah, Indonesia \\ Email: khabibatulhikmah123@gmail.com 088801985057
}

Submitted :

Reviewed :

Accepted:.

\begin{abstract}
ABSTRAK
Penyakit Scabies (kudis) merupakan salah satu penyakit kulit yang sering dijumpai dan kurang diperhatikan oleh para santri di Pondok Pesantren. Mereka menganggap kebiasaan dalam menjaga kebersihan diri sudah cukup dan tidak akan menimbulkan masalah kesehatan khususnya penyakit kulit. Penelitian ini bertujuan untuk mengetahui hubungan tingkat pengetahuan dan kepatuhan pengobatan terhadap waktu kesembuhan penyakit scabies pada santri di Yayasan Islam Al-Sya'iriyah. Metode yang digunakan adalah survei analitik dengan rancangan cross sectional. Hasil penelitian ini menujukkan tingkat pengetahuan yang baik $(74,2 \%)$ dan tingkat kepatuhan pengobatan santri yang patuh sebanyak $(62,2 \%)$. Pada penelitian ini menunjukkan adanya hubungan antara pengetahuan dengan waktu kesembuhan penyakit scabies dan adanya hubungan antara pengetahuan dengan waktu kesembuhan penyakit scabies dengan probilitas Chi Square sebanyak 0,000 <0,05.
\end{abstract}

Kata kunci : Kepatuhan; kesembuhan; pengetahuan

\begin{abstract}
Scabies disease is one of the skin diseases that is often encountered and is not paid attention to by students at Islamic Boarding Schools. They consider the habit of maintaining personal hygiene is sufficient and will not cause health problems, especially skin diseases. This study aims to determine the relationship between the level of knowledge and medication adherence to the healing time of scabies in students at the Al-Syairiyah Islamic Foundation. The method used is an analytical survey with a cross sectional design. The results of this study indicate a good level of knowledge (74.2\%) and the level of adherence to treatment of students who are obedient (62.2\%). This study shows that there is a relationship between knowledge and healing time of scabies and there is a relationship between knowledge and healing time of scabies with a Chi Square probability of $0.000<0.05$.
\end{abstract}

Keywords: Obedience; recovery; knowledge

\section{Penulis Korespondensi :}

Khabibatul Khikmah

Universitas Muhammadiyah Pekajangan Pekalongan

Jl. Raya Ambuekembang No.8 Kedungwuni, Pekalongan, Jawa Tengah, Indonesia

Email: khabibatulhikmah123@gmail.com 088801985057 


\section{PENDAHULUAN}

Scabies merupakan salah satu penyakit kulit yang disebabkan oleh tungau (kutu kecil) yaitu Sarcoptes scabiei varietas hominis. Penyakit tersebut merupakan masalah kesehatan bagi masyarakat terutama diwilayah beriklim tropis dan subtropis. Faktor yang berperan pada tingginya prevalensi scabies adalah kepadatan penghuni rumah, rendahnya tingkat pendidikan, keterbatasan air bersih, dan perilaku kebersihan yang buruk. Tingginya kepadatan penghuni disertai interaksi dan kontak fisik yang erat sangat memudahkan penularan penyakit scabies. Kepadatan penghuni merupakan salah satu faktor paling dominan dibandingkan faktor risiko scabies lainnya. Berdasarkan faktor risiko tersebut prevalensi scabies yang paling tinggi umumnya terdapat di asrama, panti asuhan, pengungsian, penjara dan pondok pesantren (Sungkar, 2016).

Adapun tujuan dari penelitian ini untuk mengetahui hubungan tingkat pengetahuan dan kepatuhan terhadap waktu kesembuhan penyakit scabies pada santri di Yayasan Islam Al-Sya'iriyah. Dimana penelitian sebelumya yang serupa dengan judul "Hubungan antara Faktor Pengetahuan dan Perilaku dengan Kualitas Hidup Penderita Skabies di Pondok Pesantren se-Malang Raya" oleh Savira tahun 2020. Terdapat persamaan pengambilan sampel yaitu dengan teknik purposive sampling atau diambil secara total yang memenuhi kreteria inklusi. Perbedaan penelitian ini yaitu menggunakan desain penelitian analitik observasional dengan desain cross sectional. Hasil penelitian menunjukkan bahwa terdapat hubungan yang tidak signifikan antara pengetahuan tentang skabies dengan kualitas hidup, dan terdapat hubungan yang tidak signifikan antara perilaku dengan kualitas hidup pada penderita skabies di Pondok Pesantren se-Malang Raya dengan probilitas > level of significance.

Tinggal bersama dengan sekelompok orang seperti halnya di pondok pesantren akan berisiko mudah tertular berbagai penyakit, kususnya scabies yang kurang diperhatikan oleh para santri di pondok pesantren. Mereka menganggap kebiasaan mereka dalam menjaga kebersihan diri sudah cukup dan tidak akan menimbulkan masalah kesehatan khusunya penyakit kulit, dari beberapa penyakit kulit seperti scabies paling sering diakibatkan dari perilaku yang tidak sehat seperti menggantung pakaian di kamar, saling bertukar pakaian, bertukar benda pribadi seperti sisir, handuk dan juga dipengaruhi oleh tingkat pengetahuan yang kurang mengenai kebersihan diri (Intan, 2016). Penyakit Scabies yang sering dijumpai dan kurang diperhatikan oleh para santri di Pondok Pesantren inilah yang membuat peneliti tertarik untuk mengetahui hubungan tingkat pengetahuan dan kepatuhan pengobatan terhadap waktu kesembuhan penyakit scabies pada santri di Pondok Pesantren Al-Sya'iriyah.

Penelitian yang dilakukan saat ini masih memiliki keterbatasan dan kekurangan peneliti yang hanya mengukur tingkat kepatuhan menggunakan instrumen kuesioner saja, sehingga untuk penelitan selanjutnya disarankan supaya melakukan tindakan pengaplikasian obat kepada responden secara langsung agar dapat diketahui tingkat kepatuhan penggunaan obat terhadap lamanya waktu sembuh penyakit scabies.

\section{METODE PENELITIAN}

Penelitian ini merupakan penelitian dalam bentuk survei analitik dengan rancangan survei cross sectional, dimana tiap subjek penelitian hanya diobservasi sekali saja dan pengukuran dilakukan terhadap status karakter atau variabel subjek pada saat pemeriksaan (Notoatmodjo, 2018). Adapun teknik pengambilan sampel pada penelitian ini menggunakan purposive sampling dengan responden (sampel) sebanyak 225 yang telah dihitung menggunakan rumus slovin.

Instrumen yang digunakan pada penelitian ini adalah kuesioner tingkat pengetahuan yang disusun oleh peneliti dan dikembangkan dari tinjauan pustaka di Bab II dengan 10 pertanyaan. Jawaban pertayaan favourable jika benar diberi skor 1 dan salah diber skor 0 . Jawaban skor unfavourable jika benar skor 0 dan salah skor 1. Kuesioner kepatuhan pengobatan menggunakan kuesioner The 8-Item Morisky Medication Adherence Scale (MMAS-8). Sedangkan untuk kuesioner yang berisi skala waktu kesembuhan yang disusun 
oleh peneliti dan dikembangkan dari tinjauan pustaka BAB II dengan tingkatan tepat waktu sembuh: 1-2 minggu, lebih lama: 2 bulan dan tidak sembuh.

\section{Jalannya Penelitian}

Adapun jalannya penelitian sebagai berikut :

1. Perijinan

2. Persetujuan dari ketua Yayasan Islam Al-Sya'iriyah dan pengasuh Pondok Pesantren

3. Penentuann Sampel penelitian dan pengambilan sampel dengan teknik Purposive Sampling

4. Menjelaskan dan memberikan lembar persetujuan dan kuesioner kepada responden

5. Meminta responden melengkapi jawaban yang belum lengkap pada kuesioner

6. Pengolahan data (Analisis data)

7. Pelaporan hasil

\section{Analisis Data}

Analisis data merupakan bagian yang sangat penting dan dapat memberikan makna yang berguna dalam menyelesaikan masalah penelitian. Analisis data dilakukan untuk mengetahui hubungan masing-masing variabel bebas dan variabel terikat. Analisis data yang digunakan yaitu :

\section{Analisis Univariat}

Analisis yang bertujuan untuk menjelaskan atau mendeskripsikan karakteristik setiap variabel penelitian. Bentuk analisis univart tergantung jenis datanya. Untuk data numerik digunakan nilai mean atau rata-rata, media dan standar deviasi. Pada umumnya dalam analisis ini hanya mnghasilkan distribusi, frekuensi dan presentase dari tiap variabel (Notoatmodjo, 2018).

2. Analisis Bivariat

Analisis Bivariat digunakan untuk menganalisis data yang dikategorikan untuk melihat hubungan antara variabel menggunakan analisis Chi Square yang merupakan uji statistik non parametik untuk melihat hubungsn antara 2 variabel. Interprestasi data menggunakan analisis Chi Square data dapat dilihat nilai signifikasi yang diperoleh. Apabila nilai signifikasi yang didapat $<0,05$ maka atara variabel 1 dan 2 memiliki hubungan yang kuatdan sebaliknya (Sani, 2018).

\section{HASIL DAN PEMBAHASAN}

A. Karakteristik Responden

1. Usia

Hasil pengambilan data karakteristik responden berdasarkan usia disajikan pada Tabel 1.1.

Tabel 1.1 Karakteristik Berdasarkan Usia Responden

\begin{tabular}{ccc}
\hline Usia $($ Tahun) & Jumlah $(\mathbf{N})$ & Persentase $\mathbf{( \% )}$ \\
\hline 13 tahun & 51 & 22,7 \\
14 tahun & 67 & 29,8 \\
15 tahun & 46 & 20,4 \\
16 tahun & 32 & 14,2 \\
17 tahun & 19 & 8,4 \\
18 tahun & 10 & 4,4 \\
\hline Total & 225 & 100 \\
\hline
\end{tabular}

Berdasarkan Tabel 1.1 dapat diinterpretasikan bahwa sebagian besar usia responden paling banyak berusia 14 tahun sebesar 29\%. Menurut Astutik (2013) faktor usia dapat mempengaruhi daya tangkap dan pola pikir seseorang, semakin bertambahnya usia maka semakin bertambah pula daya tangkap dan pola pikir 
seseorang tersebut. Sedangkan menurut Giovano (2016) bisa menyerang semua orang dan semua umur, tetapi untuk usia anak sekolah dan remaja lebih rentan terserang scabies. Hal ini telah dibuktikan pada penelitian Nurdianawati (2017) di Pondok Pesantren Al-Aqobah Kwaron Diwek Jombang dari seluruh data responden dari usia 12 hingga 18 tahun menunjukan bahwa sebagian besar dari responden berusia 12 sampai 15 tahun yaitu sebanyak 26 responden.

2. Jenis Kelamin

Hasil pengambilan data karakteristik responden berdasarkan usia disajikan pada Tabel 1.1.

Tabel 1.2 Karakteristik Berdasarkan Jenis Kelamin Responden

\begin{tabular}{ccc}
\hline Jenis Kelamin & Jumlah (N) & Persentase (\%) \\
\hline Perempuan & 144 & 64 \\
Laki-laki & 81 & 36 \\
\hline Total & & 100 \\
\hline
\end{tabular}

(Data diolah, 2021)

Berdasarkan tabel 1.2 dapat diinterpretasikan bahwa hasil pengambilan data jenis kelamin sebagian besar berjenis kelamin perempuan dengan persentase $64 \%$. Sedangkan menurut sungkar (2016) skabies dapat menginfestasi laki-laki maupun perempuan, tetapi laki-laki lebih sering menderita skabies. Hal tersebut disebabkan karena laki-laki kurang memperhatikan kebersihan diri dibandingkan dengan perempuan. Pada penelitin ini didapati sebanyak $64 \%$ berjenis kelamin perempuan dan $36 \%$ berjenis kelamin laki-laki. Hal ini disebabkan karena banyaknya jumlah banyaknya santriwati yang menetap dan tinggal di Pondok Pesantren.

3. Tingkat Pendidikan

Hasil pengambilan data karakteristik responden berdasarkan tingkatan pendidikan dipaparkan pada Tabel 1.3.

Tabel 1.3 Karakteristik Berdasarkkan Pendidikan Responden

\begin{tabular}{ccc}
\hline Pendidikan & Jumlah $(\mathbf{N})$ & Persentase (\%) \\
\hline SMP / MTs & 144 & 64 \\
MA / SMK & 81 & 36 \\
\hline Total & 225 & 100 \\
\hline & & (Data diolah, 2021)
\end{tabular}

Berdasarkan tabel 1.3 dapat diinterpretasikan sebagian besar pendidikan responden paling banyak SMP/MTs sejumlah 114 responden (64\%). Hal ini sesuai dengan teori Notoatmodjo (2012) bahwasanya pendidikan merupakan suatu proses belajar yang berarti dalam pendidikan itu terjadi proses pertumbuhan, perkembangan, atau kearah yang lebih dewasa, lebih baik dan lebih matang pada diri individu, keluarga atau masyarakat. Penelitian sebelumnya oleh Nurdianawati (2017) di Pondok Pesantren Al-Aqobah Kwaron Diwek Jombang menunjukkan bahwa dari 48 responden sebagian besar berpendidikan SMP sejumlah 26 responden $(54,2 \%)$. Jadi dapat ditarik kesimpulan bahwa semakin tinggi pedidikan seseorang maka akan semakin bertambah pula wawasannya sehingga hasil pada penelitian ini menunjukkan sebagian santri yang menderita scabies adalah santri dengan tingkat pendidikan SMP/MTs yang kurang sadar akan pentingnya menjaga kebersihan diri. 
4. Pembelian Obat

Berikut merupakan data karakteristik responden berdasarkan pembelian obat: Tabel 1.4 Karakteristik Berdasarkkan Pembelian Obat

\begin{tabular}{ccc}
\hline Pembelian Obat di & Jumlah & Persentase (\%) \\
\hline Apotek & 196 & 87,1 \\
Warung / Toko Kelontong & 27 & 12 \\
Online & 2 & 0,9 \\
\hline Total & 225 & 100 \\
\hline
\end{tabular}

(Data diolah, 2021)

Berdasarkan tabel 1.4 dapat diinterpretasikan, sebagian besar pembelian obat yang paling banyak adalah pembelian di Apotek dengan persentase 87,1\%. Menurut Keputusan Mentri Kesehatan Republik Indonesia Nomor : 1332/Menkes/SK/X/2002 dalam (Hapsari.,et al. 2013) Apotek adalah suatu tempat tertentu, tempat dilakukan pekerjaan kefarmasian dan penyaluran sediaan farmasi. Hal ini sesuai dengan teori diatas bahwasanya apotek merupakan sarana untuk pembelian responden $(87,1 \%)$.

5. Sumber Informasi

Berikut merupakan data karakteristik responden berdasarkan sumber informasi yang diperoleh :

Tabel 1.5 Karakteristik Berdasarkan Pembelian Obat

\begin{tabular}{ccc}
\hline Sumber Informasi & Jumlah (N) & Persentase (\%) \\
\hline Media massa seperti televisi, radio & 8 & 3,6 \\
dan internet & & \\
Teman & 95 & 42,2 \\
Pengalamn Pribadi & 122 & 54,2 \\
\hline Total & 225 & 100 \\
\hline & & (Data diolah, 2021)
\end{tabular}

Berdasarkan tabel 1.5 dapat diinterpretasikan bahwa sebagian besar sumber informasi yang diperoleh dari pengalaman pribadi dengan persentase 54,2\%, sedangkan sumber informasi yang diperoleh dari teman sebanyak $42,2 \%$ dan dari Media massa seperti televisi, radio, internet dll. sebanyak 3,6\%. Menurut Astutik (2013) jika seseorang memiliki pengetahuan yang rendah, namun mendapatkan informasi yang baik dari berbagai media seperti televisi radio, surat kabar, majalah dan lain-lain maka hal tersebut dapat meningkatkan pengetahuan seseorang.

Hal ini sesuai dengan data yang diperoleh pada Tabel 1.5 bahwasanya sumber informasi yang paling banyak didapati dari pengalaman sendiri $(54,2 \%)$ Pengalaman adalah suatu proses dalam memperoleh kebenaran pengetahuan dengan cara mengulang kembali pengetahuan yang telah diperoleh dalam memecahkan masalah yang dihadapi saat masa lalu dan dapat digunakan dalam upaya memperoleh pengetahuan (Astutik, 2013). Sedangkan sumber informasi dari media massa seperti televisi, radio dan internet itu jarang digunakan oleh kalangan santri dikarenakan peraturan pondok pesantren untuk tidak membawa berbagai macam barang elektronik.

B. Analisis Univariat

1. Pengetahuan

Distribusi Frekuensi Penderita Scabies di Yayasan Islam Al-Sya'iriyah Berdasarkan Pengetahuan Scabies dapat disajikan pada table 1.6. 
Tabel 1.6 Analisis Distribusi Frekuensi Pengetahuan

\begin{tabular}{ccc}
\hline Pengetahuan & Jumlah (N) & Persentase (\%) \\
\hline Kurang & 13 & 5,8 \\
Cukup & 45 & 20 \\
Baik & 167 & 74,2 \\
\hline Total & 225 & 100 \\
\hline & & (Data diolah, 2021)
\end{tabular}

Berdasarkan Tabel 1.6 dapat diketahui bahwa dari 225 responden penderita penyakit scabies di Pondok Pesantren yang berada di Yayasan Islam Al-Sya'iriyah yang berpartisipasi dalam penelitian ini, yaitu: sebanyak 5,8\% penderita scabies di Yayasan Islam Al-Sya'iriyah memiliki pengetahuan yang kurang, sedangkan sebanyak $20 \%$ penderita scabies di Yayasan Islam Al-Sya'iriyah memiliki pengetahuan yang cukup dan $74,2 \%$ penderita scabies di Yayasan Islam AlSya'iriyah memiliki pengetahuan yang baik. Hal ini menunjukkan bahwa dari 225 responden penderita scabies di Pondok Pesantren yang berada di Yayasan Islam Al-Sya'iriyah memiliki pengetahuan penyakit scabies yang baik dengan hasil persentase $74,2 \%$. Hasil penelitian tersebut sesuai dengan penelitian Savira (2020) bahwa penderita scabies di pondok pesantren se-Malang Raya memiliki pengetahuan yang baik.

2. Kepatuhan Pengobatan

Distribusi Frekuensi Penderita Scabies di Yayasan Islam Al-Sya'iriyah Berdasarkan Kepatuhan Pengobatan dapat disajikan pada tabel 1.7.

Tabel 1.7 Analisis Distribusi Frekuensi Kepatuhan Pengobatan

\begin{tabular}{ccc}
\hline Kepatuhan Pengobatan & Jumlah $(\mathbf{N})$ & Persentase (\%) \\
\hline Tidak Patuh & 85 & 37,8 \\
Patuh & 140 & 62,2 \\
\hline Total & 225 & 100 \\
\hline
\end{tabular}

(Data diolah, 2021)

Berdasarkan Tabel 1.6 dapat diketahui bahwa dari 225 responden penderita penyakit scabies di Pondok Pesantren yang berada di Yayasan Islam Al-Sya'iriyah yang berpartisipasi dalam penelitian ini, yaitu: sebanyak 37,8\% penderita scabies di Yayasan Islam Al-Sya'iriyah memiliki kepatuhan pengobatan dengan kategori tidak patuh, sedangkan sebanyak $62,2 \%$ penderita scabies di Yayasan Islam AlSya'iriyah memiliki kepatuhan pengobatan dengan kategori patuh. Hal ini menunjukkan bahwa dari 225 responden penderita scabies di Pondok Pesantren yang berada di Yayasan Islam Al-Sya'iriyah memiliki kepatuhan pengobatan scabies dengan jumlah santri yang patuh sebanyak $62,2 \%$. Penelitian sebelumnya belum ada yang meneliti mengenai kepatuhan scabies sehingga peneliti tidak dapat membandingkan hasil kepatuhan pengobatan scabies dari penelitian sebelumnya.

3. Skala Waktu Sembuh Scabies

Distribusi Frekuensi Penderita Scabies di Yayasan Islam Al-Sya'iriyah Berdasarkan Skala Waktu Sembuh Scabies dapat disajikan pada tabel 1.8.

Tabel 1.8 Analisis Distribusi Frekuensi Skala Waktu Sembuh

\begin{tabular}{ccc}
\hline Kategori & Frekuensi & Persentase (\%) \\
\hline Tidak Sembuh & 19 & 8,4 \\
Lebih Lama & 52 & 23,1 \\
Tepat Waktu & 154 & 68,4 \\
Sembuh & & \\
\hline Total & 225 & (Data diolah, 2021)
\end{tabular}


Berdasarkan tabel 1.8 dapat diketahui bahwa dari 225 responden penderita penyakit scabies di Pondok Pesantren yang berada di Yayasan Islam Al-Sya'iriyah yang berpartisipasi dalam penelitian ini, yaitu: sebanyak $8,4 \%$ penderita scabies di Yayasan Islam Al-Sya'iriyah memiliki skala waktu sembuh dengan kategori tidak sembuh, sedangkan sebanyak $23,1 \%$ penderita scabies di Yayasan Islam AlSya'iriyah memiliki skala waktu sembuh dengan kategori lebih lama dan 68,4\% penderita scabies di Yayasan Islam Al-Sya'iriyah memiliki sakala waktu sembuh dengan kategori tepat waktu sembuh. Hal ini menunjukkan bahwa dari 225 responden penderita scabies di Pondok Pesantren yang berada di Yayasan Islam Al-Sya'iriyah sebagian besar memiliki skala waktu sembuh penyakit scabies dengan kategori tepat waktu sembuh $68,4 \%$.

C. Analisis Bivariat

Tabel 1.9 Pengetahuan Terhadap Waktu Kesembuhan

\begin{tabular}{|c|c|c|c|c|c|c|}
\hline & \multicolumn{5}{|c|}{ Waktu Kesembuhan } \\
\hline & & & & & Tepat Waktu & \\
\hline & & & Tidak Sembuh & Lebih Lama & Sembuh & Total \\
\hline \multirow{6}{*}{$\begin{array}{l}\text { Pengetahu } \\
\text { an }\end{array}$} & \multirow{2}{*}{ Kurang } & Count & 5 & 4 & 4 & 13 \\
\hline & & $\begin{array}{l}\% \text { of } \\
\text { Total }\end{array}$ & $2.2 \%$ & $1.8 \%$ & $1.8 \%$ & $5.8 \%$ \\
\hline & \multirow[t]{2}{*}{ Cukup } & Count & 6 & 16 & 23 & 45 \\
\hline & & $\begin{array}{l}\% \text { of } \\
\text { Total }\end{array}$ & $2.7 \%$ & $7.1 \%$ & $10.2 \%$ & $20.0 \%$ \\
\hline & \multirow[t]{2}{*}{ Baik } & Count & 8 & 32 & 127 & 167 \\
\hline & & $\begin{array}{l}\% \text { of } \\
\text { Total }\end{array}$ & $3.6 \%$ & $14.2 \%$ & $56.4 \%$ & $74.2 \%$ \\
\hline \multirow[t]{2}{*}{ Total } & & Count & 19 & 52 & 154 & 225 \\
\hline & & $\begin{array}{l}\% \text { of } \\
\text { Total }\end{array}$ & $8.4 \%$ & $23.1 \%$ & $68.4 \%$ & $100.0 \%$ \\
\hline
\end{tabular}

(Data diolah, 2021)

Hasil perhitungan pada tabel 1.9 menunjukkan bahwa dari 225 responden yakni penderita yang memiliki pengetahuan scabies kurang dengan pengaruh waktu kesembuhan yang tidak sembuh adalah 2,2\%; sedangkan penderita yang memiliki pengetahuan scabies kurang dengan pengaruh waktu kesembuhan yang lebih lama adalah 1,8\%; dan penderita yang memiliki pengetahuan scabies kurang dengan pengaruh waktu kesembuhan yang tepat waktu sembuh adalah $1,8 \%$. Hal ini menunjukkan bahwa sebagian besar penderita scabies di Pondok Pesantren Yayasan Islam Al-Sya'iriyah yang memiliki tingkat pengetahuan yang kurang, memiliki pengaruh waktu sembuhan yang tidak sembuh $(2,2 \%)$.

Selanjutnya dari 225 penderita scabies di Pondok Pesantren Yayasan Islam Al-Sya'iriyah yaitu penderita yang memiliki pengetahuan scabies cukup dengan pengaruh waktu kesembuhan yang tidak sembuh adalah $2,7 \%$; sedangkan penderita yang memiliki pengetahuan scabies cukup dengan pengaruh waktu kesembuhan yang lebih lama adalah $7,1 \%$; dan penderita yang memiliki pengetahuan scabies cukup dengan pengaruh waktu kesembuhan yang tepat waktu sembuh adalah 10,2\%. Hal ini menunjukkan bahwa sebagian besar penderita scabies di Pondok Pesantren Yayasan Islam Al-Sya'iriyah yang memiliki tingkat pengetahuan yang cukup, memiliki pengaruh waktu sembuhan yang tepat waktu sembuh $(10,2 \%)$. 
Selanjutnya dari 225 penderita scabies di Pondok Pesantren Yayasan Islam Al-Sya'iriyah yaitu penderita yang memiliki pengetahuan scabies baik dengan pengaruh waktu kesembuhan yang tidak sembuh adalah 3,6\%; sedangkan penderita yang memiliki pengetahuan scabies baik dengan pengaruh waktu kesembuhan yang lebih lama adalah 14,2\%; dan penderita yang memiliki pengetahuan scabies baik dengan pengaruh waktu kesembuhan yang tepat waktu sembuh adalah 56,4\%. Hal ini menunjukkan bahwa sebagian besar penderita scabies di Pondok Pesantren Yayasan Islam Al-Sya'iriyah yang memiliki tingkat pengetahuan yang baik, memiliki pengaruh waktu sembuhan yang tepat waktu sembuh $(56,4 \%)$.

Pengujian hubungan tingkat pengetahuan terhadap waktu kesembuhan scabies pada santri di Pondok Pesantren Yayasan Islam Al-Sya'iriyah dilakukan menggunakan Chi Square. Nilai hasil tersebut menunjukkan probabilitas Chi Square sebanyak 0,000. Hasil tersebut menunjukkan probabilitas < level of significance $(\alpha=0,05)$. Dengan demikian dapat dinyatakan ada hubungan yang signifikan antara pengetahuan terhada waktu kesembuhan penyakit scabies pada santri di Pondok Pesantren Yayasan Islam Al-Sya'iriyah.

Santri yang terlibat dalam penelitian ini telah memahami dan mengetahui halhal yang berkaitan dengan penyakit scabies. Hal tersebut dapat dilihat dari hasil penelitian yaitu sebanyak santri memiliki pengetahuan yang 5,8\% penderita scabies di Yayasan Islam Al-Sya'iriyah memiliki pengetahuan yang kurang, sedangkan sebanyak $20 \%$ penderita scabies di Yayasan Islam Al-Sya'iriyah memiliki pengetahuan yang cukup dan $74,2 \%$ penderita scabies di Yayasan Islam AlSya'iriyah memiliki pengetahuan yang baik. Sama halnya dengan penelitian Savira (2020) yang dilakukan pada 90 santri di Pondok Pesantren se-Malang Raya yang menunjukkan hasil bahwa sebagian besar santri memiliki hasil pengetahuan yang baik.

Semakin baik tingkat pengetahuan responden maka akan berpengaruh terhadap waktu sembuh pada penyakit scabies tersebut. Sehingga semakin baik tingkatan pengetahuan sesorang maka akan semakin cepat sembuh. Hal ini dipertegas oleh penelitian Yusri (2014) responden yang berpengetahuan tinggi tentang scabies cenderung untuk tidak mengalami kejadian scabies karena responden mengetahui dan memahami apa itu scabies, faktor penyebab scabies dan cara penanganannya sehingga santri mampu bertindak dan berperilaku untuk menghindari kejadian scabies.

Tabel 1.10 Pengetahuan Terhadap Waktu Kesembuhan

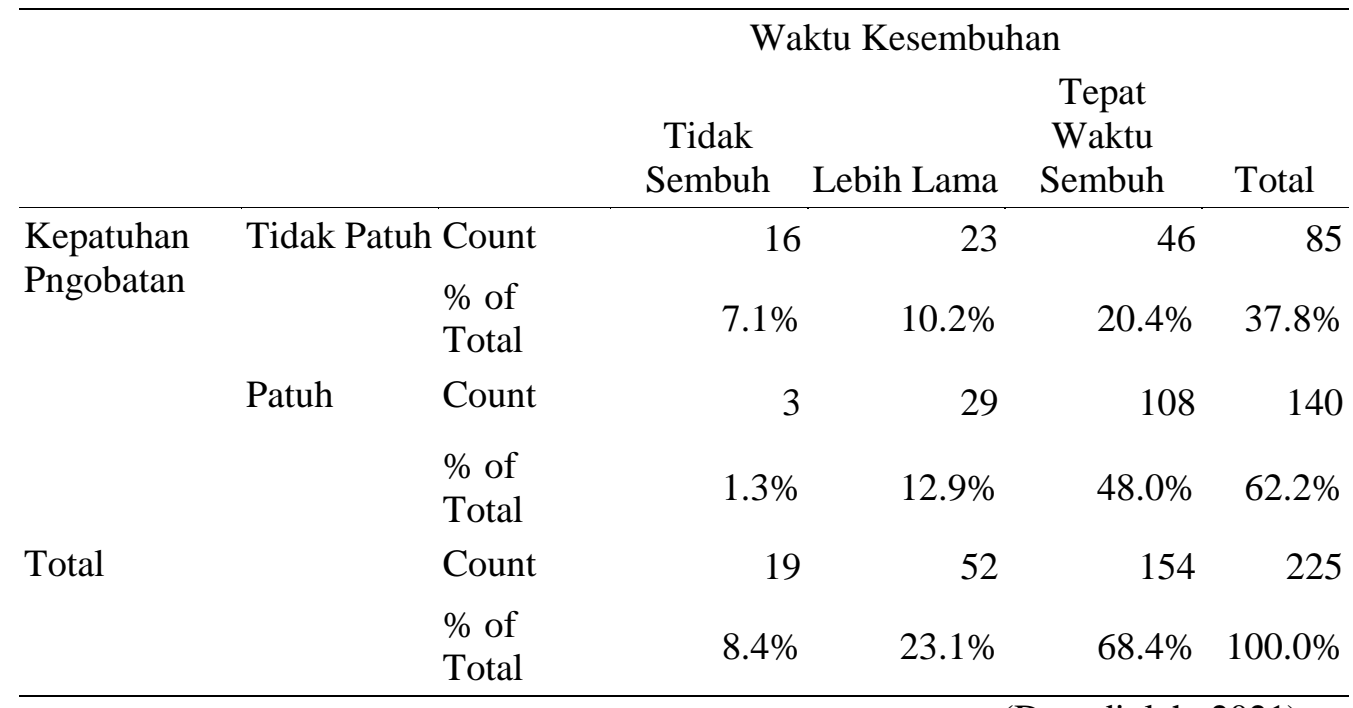

(Data diolah, 2021) 
Hasil perhitungan menunjukkan bahwa dari 225 responden yakni penderita yang memiliki kepatuhan pengobatan yang tidak patuh dengan pengaruh waktu kesembuhan yang tidak sembuh adalah $7,1 \%$; sedangkan penderita yang memiliki kepatuhan pengobatan yang tidak patuh dengan pengaruh waktu kesembuhan yang lebih lama adalah 10,2\%; dan penderita yang memiliki kepatuhan pengobatan yang tidak patuh dengan pengaruh waktu kesembuhan yang tepat waktu sembuh adalah 20,4\%. Hal ini menunjukkan bahwa sebagian besar penderita scabies di Pondok Pesantren Yayasan Islam Al-Sya'iriyah yang memiliki kepatuhan pengobatan yang tidak patuh, memiliki pengaruh waktu sembuhan yang tepat waktu sembuh $(20,4 \%)$. Selanjutnya dari 225 penderita scabies di Pondok Pesantren Yayasan Islam Al-Sya'iriyah yaitu penderita yang memiliki kepatuhan pengobatan yang patuh dengan pengaruh waktu kesembuhan yang tidak sembuh adalah 7,1\%; sedangkan penderita yang memiliki kepatuhan pengobatan yang patuh dengan pengaruh waktu kesembuhan yang lebih lama adalah 10,2\%dan penderita yang memiliki kepatuhan pengobatan yang patuh dengan pengaruh waktu kesembuhan yang tepat waktu sembuh adalah20,4\%. Hal ini menunjukkan bahwa sebagian besar penderita scabies di Pondok Pesantren Yayasan Islam Al-Sya'iriyah yang memiliki tingkat pengetahuan yang cukup, memiliki pengaruh waktu kesembuhan yang tepat waktu sembuh $(10,2 \%)$.

Selanjutnya dari 225 penderita scabies di Pondok Pesantren Yayasan Islam Al-Sya'iriyah yaitu penderita yang memiliki pengetahuan scabies baik dengan pengaruh waktu kesembuhan yang tidak sembuh adalah 1,3\%; sedangkan penderita yang memiliki pengetahuan scabies baik dengan pengaruh waktu kesembuhan yang lebih lama adalah $12,9 \%$; dan penderita yang memiliki pengetahuan scabies baik dengan pengaruh waktu kesembuhan yang tepat waktu sembuh adalah 48\%. Hal ini menunjukkan bahwa sebagian besar penderita scabies di Pondok Pesantren Yayasan Islam Al-Sya'iriyah dengan kepatuhan pengobatan yang patuh, memiliki pengaruh waktu kesembuhan yang tepat waktu sembuh (48\%).

Pengujian hubungan tingkat pengetahuan terhadap waktu kesembuhan scabies pada santri di Pondok Pesantren Yayasan Islam Al-Sya'iriyah dilakukan menggunakan Chi Square. Nilai hasil tersebut menunjukkan probabilitas Chi Square sebanyak 0,000. Hasil tersebut menunjukkan probabilitas < level of significance $(\alpha=0,05)$. Dengan demikian dapat dinyatakan ada hubungan yang signifikan antara pengetahuan terhada waktu kesembuhan penyakit scabies pada santri di Pondok Pesantren Yayasan Islam Al-Sya'iriyah.

Penelitian ini dapat dilihat bahwa kepatuhan pengobatan akan sangat mempengaruhi waktu kesembuhan penyakit scabies. Semakin patuh atau rutin seseorang terhadap pengobatan scabies maka akan semakin sadar bahwa kepatuhan sangat bermanfaat bagi kesehatannya terutama untuk mencapai keberhasilan terapi pengobatan. Pada penelitian ini sebanyak $37,8 \%$ penderita scabies di Yayasan Islam Al-Sya'iriyah memiliki kepatuhan pengobatan dengan kategori tidak patuh, sedangkan sebanyak $62,2 \%$ penderita scabies di Yayasan Islam Al-Sya'iriyah memiliki kepatuhan pengobatan dengan kategori patuh. Adapun faktor-faktor yang dapat menyebabkan ketidakpatuhan yaitu: kurang pahamnya tentang pengobatan, tidak mengertinya pasien tentang pentingnya mengikuti aturan pengobatan yang ditetapkan dan mahalnya harga obat (Padila, 2014). 


\section{KESIMPULAN}

Berdasarkan penelitian yang telah dilakukan dapat disimpulkan bahwa tingkat pengetahuan scabies di Pondok Pesantren yang berada di Yayasan Islam Al-Sya'iriyah memiliki pengetahuan penyakit scabies yang baik dengan hasil persentasi 74,2 \%. Kepatuhan pengobatan scabies di Pondok Pesantren yang berada di Yayasan Islam AlSya'iriyah memiliki kepatuhan pengobatan scabies untuk santri yang patuh sebanyak 62,2\%.

Sebagian besar penderita scabies di Pondok Pesantren Yayasan Islam Al-Sya'iriyah yang mempunyai tingkat pengetahuan yang baik, memiliki pengaruh waktu kesembuhan yang tepat waktu sembuh $(56,4 \%)$. Sehingga pada penelitian ini terdapat hubungan antara pengetahuan dengan waktu kesembuhan penyakit scabies dengan probabilitas Chi Square sebanyak 0,000. Sebagian besar penderita scabies di Pondok Pesantren yang berada di Yayasan Islam Al-Sya'iriyah dengan tingkat kepatuhan pengobatan penyakit scabies untuk santri yang patuh memiliki pengaruh waktu kesembuhan yang tepat waktu sembuh (48\%) Sehingga pada penelitian ini terdapat hubungan antara Kepatuhan dengan waktu kesembuhan penyakit scabies dengan probabilitas Chi Square sebanyak 0,000.

\section{DAFTAR PUSTAKA}

Astutik, 2013, Data dan Riset Keseehatan Daerah Dasar: Riskesdas

Giovano, I. A., 2016, Faktor-Faktor Yang Berhubungan Dengan Scabies Di Pondok Pesantren Jabal An-Nur Al-Islami Kecamatan Teluk Betung Barat Kota Bandar Lampung, Skripsi, Fakultas Kedokteran Universitas Lampung.

Hapsari et al., 2013. Undang-Undang Kesehatan untuk SMK Farmasi: EGC, Jakarta.

Notoatmodjo Soekidjo, 2012, Metodologi Penelitian Kesehatan, PT Rineka cipta, Jakarta.

Notoatmodjo Soekidjo, 2018, Metodologi Penelitian Kesehatan, PT Rineka cipta, Jakarta.

Nurdianawati, Devi, 2017, Hubungan Self Care dengan Kejadian Penyakit Scabies (Studi di Pondokn Pesantren Al-Aqobah Kwaron Diwek Jombang), Skripsi, STIKES Insan Cendekia Medika, Jombang.

Padila, 2014, Buku Ajar Keperawatan Keluarga Keluarga, Nuha Medika, Yogyakarta.

Sani, Fathur, 2018, Metodologi Penelitian Farmasi Komunitas dan Eksperimental. Dee Publhiser: Yogyakarta.

Savira, Tasalsa Dzikria., 2020, Hubungan Antara Faktor Pengetahuan dan Perilaku dengan Kualitas Hidup Penderita Skabies di Pondok Pesantren Se-Malang Raya, Skripsi, Fakultas Kedokteran dan Ilmu Kesehatan, Universitas Islam Negri Maulana Malik Ibrahim Malang, Malang

Sungkar, Sahela. 2016, "Skabies Etiologi, Patogenesis, Pengobatan, Pemberantasan, dan Pencegahan”, FKUI-Jakarta.

Yusri, Wijayanti Widya, 2014, Faktor-Fsktor yang Mempengaruhi Tejadinya Penyakit Scabies di Poli Kulit dan Kelamin RSUD Dr. Achmad Mochtar Bukittinggi Tahun 2014, Skripsi, STIKES Perintis Sumbar, Sumatra Barat 